\author{
RESEARCH ARTICLE \\ 10.1029/2019JC015414 \\ Key Points: \\ - Deoxygenation processes occur in \\ the northern limit of OMZ off \\ Mexico \\ - Thinning of the hypoxic layer affects \\ its inhabitants in different ways \\ - Fish larvae of some species show \\ resilience to changes of dissolved \\ oxygen
}

Supporting Information:

- Supporting Information S1

Correspondence to:

L. Sánchez-Velasco,

lsvelasc@gmail.com

Citation:

Sánchez-Velasco, L., Godínez, V. M., Ruvalcaba-Aroche, E. D., MárquezArtavia, A., Beier, E., Barton, E. D., \& Jiménez-Rosenberg, S. P. A. (2019). Larval fish habitats and deoxygenation in the northern limit of the oxygen minimum zone off Mexico. Journal of Geophysical Research: Oceans, 124. 9690-9705. https://doi.org/10.1029/ 2019JC015414

Received 26 JUN 2019

Accepted 9 DEC 2019

Accepted article online 28 Dec 2019

Published online 30 DEC 2019

(C)2019. American Geophysical Union. All Rights Reserved.

\section{Larval Fish Habitats and Deoxygenation in the Northern Limit of the Oxygen Minimum Zone off Mexico}

\author{
Laura Sánchez-Velasco $^{1}$, Víctor M. Godínez ${ }^{2}$ (D) Erick D. Ruvalcaba-Aroche ${ }^{1}$ (D), \\ Amaru Márquez-Artavia ${ }^{1}$ (D), Emilio Beier ${ }^{3}$, Eric D. Barton ${ }^{4}$, and \\ S. Patricia A. Jiménez-Rosenberg ${ }^{1}$ (iD) \\ ${ }^{1}$ Instituto Politécnico Nacional - Centro Interdisciplinario de Ciencias Marinas, Departamento de Plancton y Ecología \\ Marina, La Paz, Mexico, ${ }^{2}$ CICESE, Departamento de Oceanografía Física, Ensenada, México, ${ }^{3}$ CICESE-Unidad La Paz, \\ Laboratorio de Macroecología Marina, La Paz, Mexico, ${ }^{4}$ Departamento de Oceanografía, Instituto Investigaciones \\ Marinas, Vigo, Spain
}

\begin{abstract}
The present state of deoxygenation in the northern limits of the shallow oxygen minimum zone off Mexico is examined in order to detect its effects on larval fish habitats and consider the sensitivity of fish larvae to decreased dissolved oxygen. A series of cruises between 2000 and 2017 indicated a significant vertical expansion of low oxygen waters. The upper limit of suboxic conditions $(<4.4 \mu \mathrm{mol} / \mathrm{kg})$ has risen $\sim 100 \mathrm{~m}$ at $19.5^{\circ} \mathrm{N}$ off Cabo Corrientes and $\sim 50 \mathrm{~m}$ at $25^{\circ} \mathrm{N}$ in the mouth of the Gulf of California. The larval habitat distribution was related to the geographic variability of dissolved oxygen and water masses between these two latitudes. One recurrent larval habitat, with Bregmaceros bathymaster larvae as the indicator species, extended throughout the water column off Cabo Corrientes from Subtropical Subsurface Water (suboxic conditions) to the surface $(220 \mu \mathrm{mol} / \mathrm{kg})$. The second recurrent habitat was located between the oxycline $(>44 \mu \mathrm{mol} / \mathrm{kg})$ and the surface in association with the Gulf of California Water, with Benthosema panamense as the indicator species. During the warm El Niño event of 2015-2016, a tropical larval fish habitat (Auxis spp.) associated with Tropical Surface Water appeared to change the larval habitat distributions. These results indicate that some species are resilient to changes of dissolved oxygen and temperature generated by El Niño events and by continuing deoxygenation, although other species with more limited environmental windows could be affected by deoxygenation, probably leading to a change of the pelagic ecosystem over time.
\end{abstract}

Plain Language Summary Dissolved oxygen in the ocean is crucial for the biological cycles of all organisms. There are vast zones in the ocean where the oxygen has dropped to levels that only a few, very well adapted, organisms can live. Dissolved oxygen measurements in the past two decades in the Mexican Pacific have shown that the concentrations have decreased, and water layers with nearly no oxygen are now closer to the surface, potentially impacting larval fish species that are not adapted to extremely low oxygen concentrations. Nevertheless, there is a set of fish larvae that is well adapted to low dissolved oxygen concentrations, principally small forage fish, which have a permanent presence in the poorly oxygenated waters, while some larvae of species with fisheries interest, like small tunids, only live in the well-oxygenated surface layer and are more abundant in warm years. The loss of oxygen in the Mexican Pacific has not had an effect on the small forage fish larvae but can affect those larvae of fish of commercial interest, with less adaptation to low oxygen concentrations.

\section{Introduction}

Deoxygenation in the oceans, which has been documented mainly on global scales (Bograd et al., 2008; Breitburg et al., 2018; Schmidtko et al., 2017; Stramma et al., 2008; Stramma et al., 2010), is of major concern for its potential effects on the nutrient cycles, the structure of marine trophic chains, and therefore availability of fishery resources (Prince \& Goodyear, 2006, Chavez \& Messié, 2009, Schmidtko et al., 2017, Cheng et al., 2015). However, more research needs to be done to precisely evaluate the consequences of deoxygenation in marine systems.

In oceanic regions where dissolved oxygen is already low, such as the shallow oxygen minimum zones (OMZs) of the eastern North Pacific Ocean (Cepeda-Morales et al., 2013; Schmidtko et al., 2017; Stramma et al., 2010), the deoxygenation process can affect the habitat of pelagic organisms from zooplankton to 
top predators (Diaz \& Rosenberg, 2008; Ekau et al., 2010; Hofmann et al., 2011; Longhurst, 1967; Prince \& Goodyear, 2006). Previous studies in this shallow OMZ (Fernandez-Alamo \& Farber-Lorda, 2006, Sánchez-Velasco et al., 2016, 2017, Ruvalcaba-Aroche et al., 2018) reported that the zooplankton biomass and total larval fish and cephalopod paralarvae had the highest abundances in the oxygenated surface layer $(>44 \mu \mathrm{mol} / \mathrm{kg})$ and decreased toward the hypoxic $(<44 \mu \mathrm{mol} / \mathrm{kg})$ and suboxic $(<4.4 \mu \mathrm{mol} / \mathrm{kg})$ conditions of the deeper layers. This is similar to findings on the vertical distribution of zooplankton in other shallow OMZs in the southeastern Pacific, Benguela and Angola Currents, and the Arabian Oceans (Madhu et al., 2003, Ekau \& Verheye, 2005, Escribano et al., 2009, Hirche et al., 2014).

The loss of dissolved oxygen in OMZs may have severe implications at the species level because critical survival thresholds may be surpassed (Schmidtko et al., 2017; Vaquer-Sunyer \& Duarte, 2008; Wishner et al., 2018), particularly for zooplanktonic organisms like fish larvae and cephalopod paralarvae, which are highly sensitive to dissolved oxygen changes (Koslow et al., 2011; Kreiner et al., 2009; Ruvalcaba-Aroche et al., 2018). Understanding the consequences of sustained deoxygenation for taxa in the planktonic life stage in OMZs is a challenge due to the lack of knowledge of how different species respond to suboxic conditions. The possible scenarios tend to be bleak because most of the physiological processes of the organisms depend on dissolved oxygen levels (Breitburg et al., 2018; Brewer \& Peltzer, 2016; Hofmann et al., 2011; Tremblay et al., 2010). However, the resilience of species to extreme changes in the environment has received little attention, probably because of the logistical difficulty of studying the issue (Tett et al., 2013).

Previous studies focusing on interannual events found that warm phases of El Niño-Southern Oscillation (ENSO) increase the diversity of the planktonic assemblages, with replacement of dominant temperate assemblages by tropical ones, while during cold phases the corresponding diversity decreases. In the absence of ENSO events, it has been assumed that most species return to their original state (Lavaniegos et al., 1998, Sánchez-Velasco et al., 2000, Cavole et al., 2016, Mcclatchie et al., 2016, Sánchez-Velasco et al., 2017); that is, most species are resilient to ENSO events. Nevertheless, it has been reported that species like northern anchovy Engraulis mordax and jumbo squid Dosidicus gigas extended their distributions to colonize adjacent ecosystems (Bazzino et al., 2010; Green-Ruiz \& Hinojosa-Corona, 1997; Hammann \& Cisneros-Mata, 1989; Zeidberg \& Robison, 2007) and did not return their distributions to pre-El Niño conditions. The northeastern Pacific Ocean contains the planet's most extended shallow OMZ (Stramma et al., 2008; Stramma et al., 2010). One of the first challenges is to know the degree of deoxygenation at local scales in that region. Even though Stramma et al. (2010) reported that the shallow OMZs have expanded and intensified globally during the past 50 years, in areas like the shallow OMZ off Mexico the lack of in situ data (Márquez-Artavia et al., 2019; Sánchez-Velasco et al., 2017) limits analysis and predictions of local conditions. The strong stratification of the water column throughout the year (Godínez et al., 2010), the intense mesoscale eddy activity of the region (Kurczyn et al., 2012), and the interannual variability dominated by the ENSO events (Godínez et al., 2010) can render difficult the detection of deoxygenation trends. The extent of the shallow OMZ off Mexico is largely governed by the convergence of surface (California Current, Gulf of California, and Tropical Surface) and intermediate (Subtropical Subsurface) water masses (Portela et al., 2016). The intermediate water mass is characterized by hypoxic and suboxic oxygen concentrations (Cepeda-Morales et al., 2013; Davies et al., 2015; Sánchez-Velasco et al., 2016).

The OMZ off Mexico can be split into two regions: the transitional area, north of $20^{\circ} \mathrm{N}$, and the tropical domain, south of $20^{\circ} \mathrm{N}$ (Cepeda-Morales et al., 2013). In the tropical domain the hydrographic conditions are similar through the year, with high surface temperature $\left(>27{ }^{\circ} \mathrm{C}\right)$, low surface salinity $(>34.6 \mathrm{~g} / \mathrm{kg}$; Portela et al., 2016), and shallow ( 60 m) hypoxic waters (Cepeda-Morales et al., 2013; Sánchez-Velasco et al., 2017). In the transition zone the surface temperatures oscillate between 18 and $30^{\circ} \mathrm{C}$, and surface salinity varies from 35.1 to $34 \mathrm{~g} / \mathrm{kg}$ during spring and autumn, respectively (Fiedler \& Talley, 2006). In spring and winter, the intrusion of the tropical branch of the California Current (Kurczyn et al., 2012) ventilates the hypoxic subsurface waters, while during summer and autumn the influence of the Mexican Coastal Current (Lavín et al., 2006; Portela et al., 2018) transport hypoxic and suboxic waters from the tropical domain to the transition zone, rising the hypoxic waters in the area (Márquez-Artavia et al., 2019).

Baseline information on the present state of the pelagic ecosystem is needed at local scales to evaluate future changes caused by the loss of oxygen in this OMZ. Fish larvae of tropical and subtropical species that inhabit the northeast Pacific Ocean (Moser, 1996) are good biological indicators of dissolved oxygen changes 

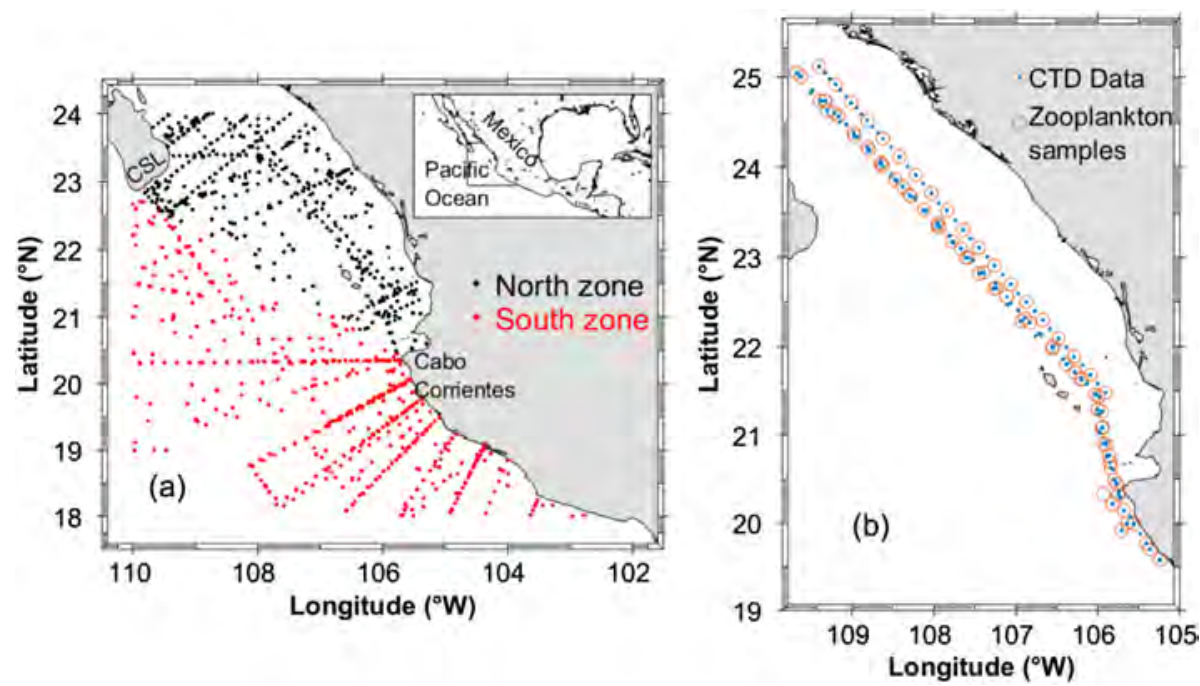

Figure 1. (a) Geographic distribution of the profiles of dissolved oxygen made from 2000 to 2017 in the northern limit of the shallow oxygen minimum zone of the tropical-subtropical convergence of the northeastern Pacific Ocean. Black points $=$ north zone; red points $=$ south zone $. \mathrm{CL}=$ Cabo San Lucas. (b) Location of CTD and zooplankton stations obtained from five oceanographic cruises made during February 2010, April 2012, June 2015, March 2016, and October 2017. Blue points $=$ CTD data; red circles $=$ zooplankton samples

because of their sensitivity to the hydrographic gradients in the water column (Apango-Figueroa et al., 2015; Contreras-Catala et al., 2016; Davies et al., 2015; Moser \& Smith, 1993; Sánchez-Velasco et al., 2017).

As a contribution to these emergent topics, in this study, the northern limit of the shallow OMZ is examined off Mexico. Evidence of progressive deoxygenation by the elevation of the oxypleths is investigated in a data set covering 2000 to 2017. It is expected that the loss of oxygen could be seen in the reduction of the hypoxic layer more than in the oxygenated layer considering the strong stratification of the water column in the study region over the year. It is also expected that any deoxygenation tendency might modify the distribution of the larvae of the fish species that inhabit that region and therefore the extension of the larval fish habitats. Due to differences in behavior and life histories, different fish species may exhibit differing responses to deoxygenation.

In this context, the aims of this study were to determine the present state of deoxygenation in the northern limit of the shallow OMZ off Mexico and to detect the effects of the dissolved oxygen gradients on the distribution of the larval fish habitats.

\section{Methodology}

\subsection{Temporal Series of Profiles of Dissolved Oxygen}

From a series of 19 oceanographic data cruises (along 10 years) made from 2000 to 2017 (see details in supporting information S1) in the northern limit of the shallow OMZ of the tropical-subtropical convergence of the northeastern Pacific Ocean, between $25^{\circ} \mathrm{N}$ and $18^{\circ} 30^{\prime} \mathrm{N}$ and $110^{\circ} \mathrm{W}$ and the coastline $\left(\sim 106^{\circ} \mathrm{W}\right.$ and $104^{\circ}$ $30^{\prime} \mathrm{W}$ ) (Figure 1a), 1,161 vertical profiles of dissolved oxygen were analyzed to detect evidence of latitudinal and vertical expansion of that shallow OMZ. Even though the spatial and temporal coverage of the cruises is irregular, the data provide a good indicator of the evolution of the dissolved oxygen conditions in the region.

On the basis of previous studies that described latitudinal dissolved oxygen gradients from SE to NW (Cepeda-Morales et al., 2013; Davies et al., 2015; Ruvalcaba-Aroche et al., 2018) and the marine ecoregions defined according to species distribution (Santamaría-del-Ángel et al., 2011), the dissolved oxygen profiles were divided into two regions: the north zone located at the mouth of the Gulf of California and the south zone off Cabo Corrientes (Figure 1a). Particularly, the northwest conductivity, temperature and depth (CTD) stations (between $20.5^{\circ} \mathrm{N}$ and $23^{\circ} \mathrm{N}$ ) are considered part of the north zone according to the Gulf of California marine ecoregion mentioned above. 


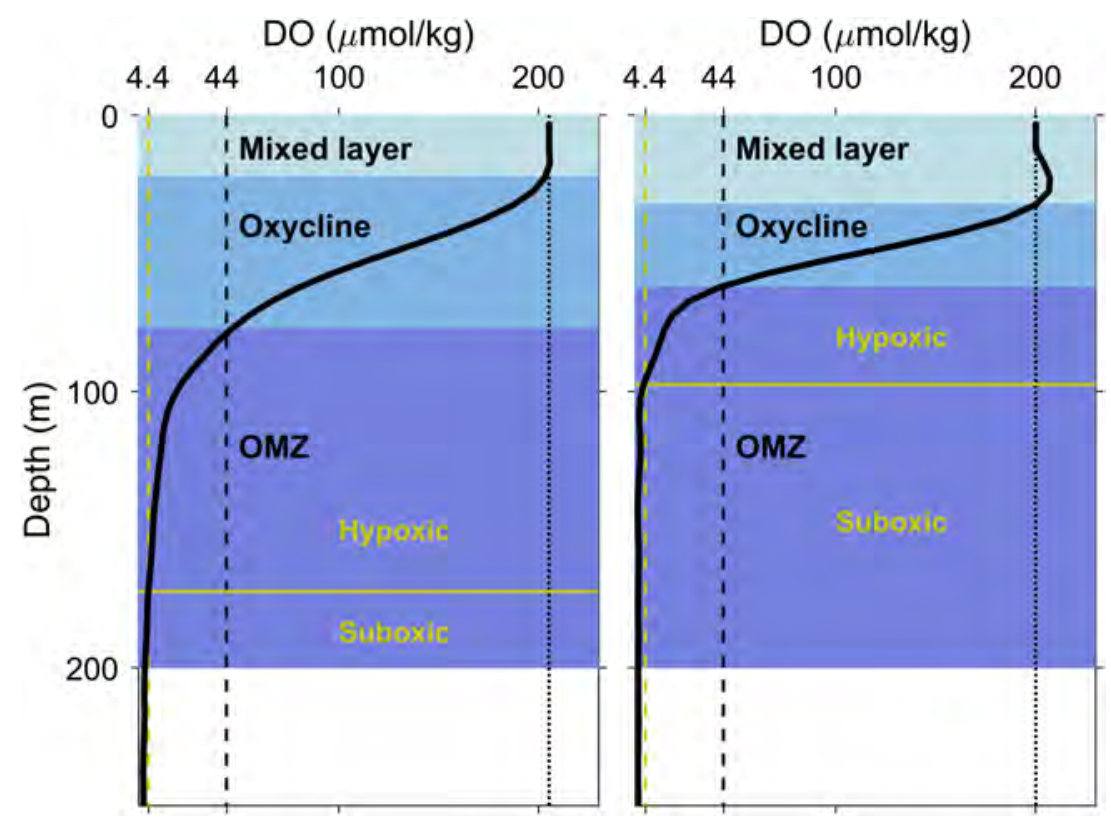

Figure 2. Example of the depth levels of the zooplankton hauls as a function of the dissolved oxygen profile in two different water columns. The continuous black line is the dissolved oxygen profile, the dashed black line is the $44 \mu \mathrm{mol} / \mathrm{kg}$ oxygen concentration, the dotted line is the surface dissolved oxygen concentration, the continuous yellow line is the limit between hypoxic and suboxic waters, and the dashed yellow line is the $4.4 \mu \mathrm{mol} / \mathrm{kg}$ oxygen concentration. The zooplankton hauls strata are represented in background colors, mixed layer (gray blue), oxycline (light blue), and oxygen minimum zone (dark blue).

The annual average depth of the 44 and $4.4 \mu \mathrm{mol} / \mathrm{kg}$ oxypleths and the vertical distance between these oxypleths were calculated, as well as the temperature and salinity of the $4.4 \mu \mathrm{mol} / \mathrm{kg}$ oxypleth in each region through the time series (see details of the data in supporting information S1). The selection of oxypleths was made on the basis of previous studies in this region (e.g., Davies et al., 2015, Sánchez-Velasco et al., 2016, Sánchez-Velasco et al., 2017, Ruvalcaba-Aroche et al., 2018). A conceptual model shows an example of the CTD profile with the oxypleths used to define the hypoxic and suboxic layers (Figure 2). For this study, we considered the $44 \mu \mathrm{mol} / \mathrm{kg}$ oxypleth, which marks the lower limit of the oxycline, as the level below which conditions are hypoxic, while the $4.4 \mu \mathrm{mol} / \mathrm{kg}$ oxypleth is the limit of suboxic conditions. The temporal trend of each variable (oxypleth depth, oxypleth difference, temperature, and salinity) was tested with a simple linear correlation test (Agresti, 2015).

\subsection{Synoptic Vision of the Zooplankton Samples and Hydrography}

CTD data and zooplankton samples were obtained from five oceanographic cruises with similar station distributions made during February 2010, April 2012, June 2015, March 2016, and October 2017 (see details in Table 1 and Figure $1 \mathrm{~b}$ ). The cruises were located in temporal context on the series of monthly average values of the multivariate ENSO index and the Pacific Decadal Oscillation (PDO) index (https://www.esrl.noaa. gov/psd/data/climateindices/list/) from 2000 to 2018.

Before zooplankton hauls, vertical profiles were obtained at each station using a SeaBird 911plus CTD probe equipped with dissolved oxygen and fluorescence sensors. Conservative temperature $\Theta\left({ }^{\circ} \mathrm{C}\right)$ and absolute salinity $\left(S_{A}, \mathrm{~g} / \mathrm{kg}\right)$ were calculated from in situ temperature and practical salinity, respectively, with the TEOS-10 (Thermodynamic Equation of Seawater-2010) software, which was downloaded from http:// www.TEOS-10.org (IOC, SCOR, IAPSO, 2010, Pawlowicz et al., 2010).

The ocean surface mixed layer depth was calculated following the methodology of Kara et al. (2000), which consists of a gradient-based criterion having a fixed temperature difference of $0.8^{\circ} \mathrm{C}$ and variable salinity. The thermocline was defined as the temperature band $\pm 1^{\circ} \mathrm{C}$ centered on the depth of the maximum temperature gradient $(\delta T / \delta z)$, which varied between cruises. 
Table 1

Details of the All Oceanographic Cruises Made in the Northern Limit of the Oxygen Minimum Zone off México

\begin{tabular}{lcccrr}
\hline & & \multicolumn{3}{c}{ Cruise name } \\
\cline { 2 - 5 } General data & MARIAS1002 & MARIAS1204 & MARIAS1506 & MARIAS1603 & MARIAS1710 \\
\hline & From 14 to & From 26 April to & From 3 to & From 2 to & From 28 October to \\
Cruise date & 27 February 2010 & 4 May 2012 & 16 June 2015 & 8 March 2016 & 24 \\
\hline No. of physical stations & 27 & 41 & 32 & 16 & 24 \\
No. of zooplankton hauls & 14 & 19 & 32 & 38 \\
No. of zooplankton samples & 33 & 57 & 39 & 16 \\
\hline
\end{tabular}

The zooplankton hauls were carried out over three depth intervals selected according to the water column structure. The first stratum was essentially the oxygenated surface mixed layer from the sea surface to the upper limit of the oxycline. The second covered the oxycline layer, from the base of the mixed layer down to the $44 \mu \mathrm{mol} / \mathrm{kg}$ oxypleth, and the third was from the base of the oxycline, at the $44 \mu \mathrm{mol} / \mathrm{kg}$ oxypleth, to $200 \mathrm{~m}$ depth. The depth of each net haul for zooplankton was selected after a visual inspection of the CTD oxygen profile. Figure 2 shows the depth levels of the zooplankton hauls in relation to two CTD oxygen profiles. The profiles of dissolved oxygen for all stations can be found in Godínez, Beier, Sánchez Velasco, \& Lavín, 2010, Godínez et al., 2012, Godínez et al., 2015, Godínez et al., 2016, Godínez et al., 2017).

The hauls were performed day and night using opening-closing conical zooplankton nets with a $60 \mathrm{~cm}$ mouth diameter, $250 \mathrm{~cm}$ net length, and $505 \mu \mathrm{m}$ mesh size (http://www.generaloceanics.com). Standard speeds of deployment ( $50 \mathrm{~m} / \mathrm{min}$ ) and recovery $(5 \mathrm{~m} / \mathrm{min}$ with $30 \mathrm{~min}$ bottom for stabilization) were made according to Smith and Richardson (1979). To estimate the true depth of each plankton tow, the depth of the net was calculated by the cosine of the wire angle method, following the standard specifications of Smith and Richardson (1979). The volume of filtered water was calculated using calibrated flow meters placed in the mouth of each net. Samples were fixed with $5 \%$ formalin buffered with sodium borate.

Zooplankton displacement volume (Beers, 1976; Kramer et al., 1972; Smith, 1971) was standardized to $\mathrm{ml} / 1,000 \mathrm{~m}^{3}$. Fish larvae were removed from all samples. These were identified according to the descriptions in Moser (1996), and abundance was standardized to number of larvae per $10 \mathrm{~m}^{2}$ (Moser \& Smith, 1993; Smith \& Richardson, 1979).

\subsection{Fish Larvae and Hydrographic Statistical Analysis}

In this study a larval fish habitat was considered as the place where a group of species coexisted during their planktonic phase (Costello, 2009). To determine the areas or habitats of fish larvae along the transects of each cruise, a cluster analysis was applied based on a species abundance matrix versus sample location (Clarke \& Ainsworth, 1993). In order to consider only the most representative species of the study area, species contributing less than $5 \%$ of the total abundance and with a frequency of occurrence $<2$ were excluded from the matrices. To reduce the weight of the most abundant species, the standardized data were fourthroot transformed. Dendrograms were constructed with the flexible agglomerative clustering method (Bray-Curtis dissimilarity index; Field et al., 1982). The cut line in the dendrograms were chosen visually, according to common practice in zooplankton and fish larvae studies (i.e., Atwood et al., 2010; Doyle et al., 1993; Moser \& Smith, 1993). To detect significant differences among the dissimilarity of the distinct larval fish habits, we applied a one-way analysis of similarities as a test of the significance of the habitats that had been defined a priori. The null hypothesis is that there are no differences between the members of the habitats (Clarke \& Ainsworth, 1993; Clarke \& Green, 1988).

The Phi coefficient (Tichý \& Chytrý, 2007) was applied in order to obtain the indicator (or diagnostic) $p$ value of a species with respect to the components of each larval fish habitat. This coefficient considers only the presence/absence of data. The Phi coefficients range from -1 (perfect negative indication) to 1 (perfect positive indication). The perfect indication means that the presence of a species points exclusively to a habitat without error, at least with the available data. The null hypothesis is that the indicator value is not larger than it would be expected at random, meaning that the species has no indicator $p$ value. If the value is less than 0.05 , the null hypothesis is rejected, meaning that the species has $p$ value as an indicator. 


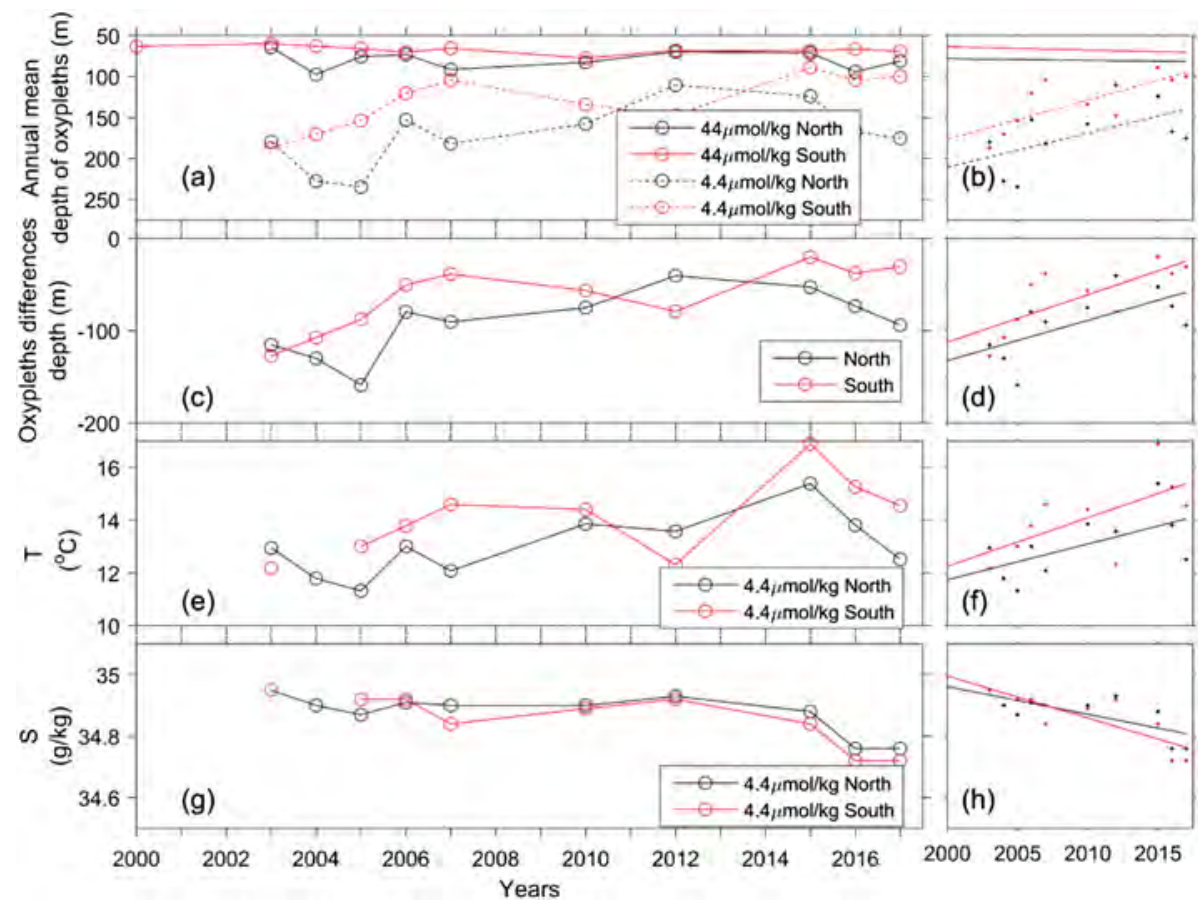

Figure 3. (a) Temporal trend of the depth of the 44 and $4.4 \mu \mathrm{mol} / \mathrm{kg}$ oxypleths from 2000 to 2017 and (b) linear regression of their trends. (c) Temporal trend of the oxypleth difference depth (m), and (d) linear regression of their trends. (e) Temporal trend of temperature values in the $4.4 \mu \mathrm{mol} / \mathrm{kg}$ oxypleths and (f) linear regression of their trends. (g) Temporal trend of salinity values in the $4.4 \mu \mathrm{mol} / \mathrm{kg}$ oxypleths and (h) linear regression of their trends.

A redundancy canonical analysis (Legendre \& Legendre, 1998) was run to define the relationship between environmental variables and larval fish distribution for the five cruises, after fourth-root transformation of the standardized biological data. This matrix contained the stratum-average values of conservative temperature $\left(\Theta,{ }^{\circ} \mathrm{C}\right)$, absolute salinity $\left(S_{A}, \mathrm{~g} / \mathrm{kg}\right)$, chlorophyll a $\left(\mathrm{mg} / \mathrm{m}^{3}\right)$, and dissolved oxygen $(\mu \mathrm{mol} / \mathrm{kg})$.

\section{Results}

\subsection{Temporal Series of Profiles of Dissolved Oxygen}

The $44 \mu \mathrm{mol} / \mathrm{kg}$ oxypleth did not show significant tendency in depth through time in either zone (Figures 3a and $3 \mathrm{~b}$ and Table 2). This oxypleth was located between $\sim 75$ and $100 \mathrm{~m}$ depth in the north zone (black continuous line) and between $\sim 65$ and $75 \mathrm{~m}$ depth in the south zone (red continuous line). However, the 4.4

Table 2

Linear Regression of the Trends of the Depth of the 44 and $4.4 \mu \mathrm{mol} / \mathrm{kg}$ Oxypleths, and Temperature (T) and Salinity (S) Values in the Depth of These Oxypleths in the North (NZ) and South (SZ) Zones in the Northern Limit of the Shallow Oxygen Minimum Zone off México

\begin{tabular}{lrccrc}
\hline Variable & Estimate & $D . f$. & $R^{2}$ & $t$ value & $p$ value \\
\hline $\mathrm{NZ}, 44 \mu \mathrm{mol} / \mathrm{kg}$ & 0.2039 & 8 & 0.01 & 1.084 & 0.794 \\
$\mathrm{SZ}, 44 \mu \mathrm{mol} / \mathrm{kg}$ & 0.4062 & 9 & 0.25 & 0.985 & 0.119 \\
$\mathrm{NZ}, 4.4 \mu \mathrm{mol} / \mathrm{kg}$ & -4.1580 & 8 & 0.31 & -1.368 & 0.096 \\
$\mathrm{SZ}, 4.4 \mu \mathrm{mol} / \mathrm{kg}$ & -4.7797 & 8 & 0.57 & -2.700 & 0.011 \\
NZ, oxipleths difference & 4.3618 & 8 & 0.41 & 1.885 & 0.046 \\
SZ, oxipleths difference & 5.1677 & 8 & 0.58 & 2.744 & 0.010 \\
NZ, T at $4.4 \mu \mathrm{mol} / \mathrm{kg}$ & 0.1359 & 8 & 0.36 & 1.668 & 0.069 \\
SZ, T at $4.4 \mu \mathrm{mol} / \mathrm{kg}$ & 0.1842 & 7 & 0.40 & 2.172 & 0.066 \\
NZ, S at $4.4 \mu \mathrm{mol} / \mathrm{kg}$ & -0.0090 & 8 & 0.52 & -2.850 & 0.018 \\
SZ, S at $4.4 \mu \mathrm{mol} / \mathrm{kg}$ & -0.0137 & 7 & 0.66 & -3.725 & 0.007 \\
\hline
\end{tabular}
$\mu \mathrm{mol} / \mathrm{kg}$ oxypleths showed a rising tendency over time in both zones (Figures $3 \mathrm{a}$ and $3 \mathrm{~b}$ ), with significant correlation in the south zone (red dashed line) (Table 2). This oxypleth shoaled from $\sim 200$ to $90 \mathrm{~m}$ depth, sinking slightly in 2017. The $4.4 \mu \mathrm{mol} / \mathrm{kg}$ oxypleth in the north (black dashed line) was elevated from $\sim 225 \mathrm{~m}$ depth in the beginning of the 2000s to $120 \mathrm{~m}$ depth in 2016 but sinking to $160 \mathrm{~m}$ depth in 2017.

In the north zone the difference in depth between the 44 and $4.4 \mu \mathrm{mol} / \mathrm{kg}$ oxypleths (black continuous line) was reduced significantly from $\sim 150 \mathrm{~m}$ at the beginning of the 2000s to $\sim 50 \mathrm{~m}$ depth in 2016, while in the south zone (red continuous line) it decreased also significantly from $\sim 150 \mathrm{~m}$ in the 2000s to $\sim 20 \mathrm{~m}$ depth at the end of the series (Figures $3 \mathrm{c}$ and $3 \mathrm{~d}$ and Table 2). In both cases the difference in depth between the oxypleths in 2017 increased.

The average temperature and salinity values at the depth of the $44 \mu \mathrm{mol} / \mathrm{kg}$ oxypleths did not show any significant tendency through time in either zone (not shown). However, the average temperature values at the depth 


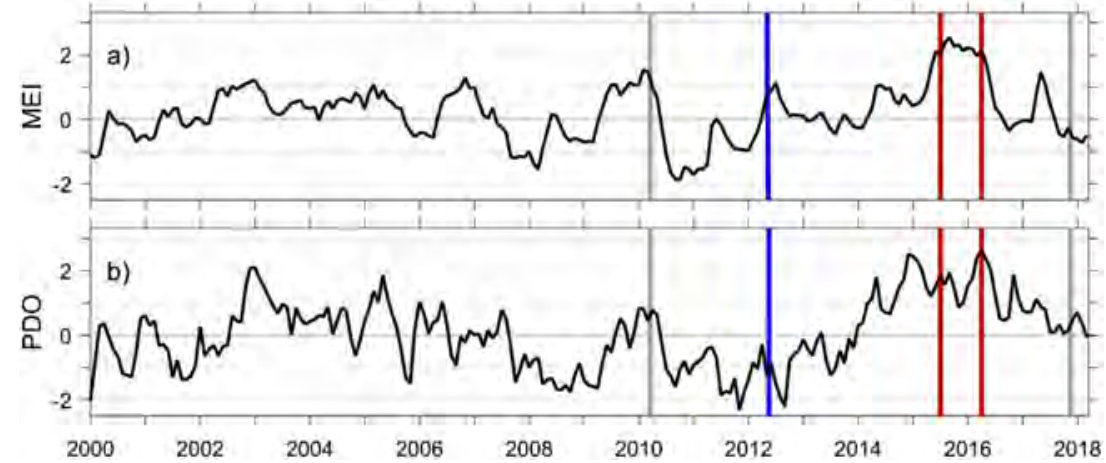

Figure 4. Fluctuations of the (a) multivariate ENSO index (MEI) and (b) Pacific Oscillation Decadal (PDO) index from 2000 to 2017. Vertical bars $=$ period when the oceanographic cruises were made; blue line $=$ under negative anomalies; red line $=$ under positive anomalies; gray line $=$ close to zero according to the PDO index.

of the $4.4 \mu \mathrm{mol} / \mathrm{kg}$ oxypleths showed a tendency to rise over time as a function of the elevation of the $4.4 \mu \mathrm{mol} / \mathrm{kg}$ oxypleths close to the values of significance in both zones (Figures $3 \mathrm{e}$ and $3 \mathrm{f}$ and Table 2). In the north zone (black continuous line) the temperature tended to increase from $\sim 12{ }^{\circ} \mathrm{C}$ at the beginning of the 2000 s to $\sim 14{ }^{\circ} \mathrm{C}$ in 2015 , decreasing to $\sim 12{ }^{\circ} \mathrm{C}$ in 2017 . In the southern zone (red continuous line), it tended to increase from $\sim 12$ to $\sim 17^{\circ} \mathrm{C}$ in 2015 , decreasing to $2{ }^{\circ} \mathrm{C}$ in 2017 , but fluctuated strongly. The salinity at the depth of the $4.4 \mu \mathrm{mol} / \mathrm{kg}$ oxypleths showed a significant decreasing tendency in both zones, like in the case of the temperature, as a function of the elevation of the $4.4 \mu \mathrm{mol} / \mathrm{kg}$ oxypleths (Figures $3 \mathrm{~g}$ and $3 \mathrm{~h}$ and Table 2).

\subsection{Geographic Variability of Dissolved Oxygen, Temperature, and Salinity}

The temporal context of the cruises that sustain the biological samplings in relation to the series of monthly average values of the multivariate ENSO index and the PDO index from 2000 to 2018 is shown in Figure 4. The cruise dates were represented with vertical lines (red lines, the two cruises that encountered the warmest conditions). The indexes displayed strong variability throughout the period, consistent between both series. Positive anomalies $\geq 2$ were observed in both indexes from mid-June 2015 to the beginning of 2016, during the warmest period of the series (red lines, June 2015 and March 2016). In contrast, negative anomalies $\geq 2$ were observed in the PDO Index series at the time of the oceanographic cruise of April 2012 (gray line).

The geographic variability of the dissolved oxygen during the five selected oceanographic cruises (Figure 5) was typified by fluctuations in the depth of the $44 \mu \mathrm{mol} / \mathrm{kg}$ oxypleth of $\sim 100 \mathrm{~m}$ in the mouth of the Gulf and $\sim 80 \mathrm{~m}$ off Cabo Corrientes. The exception was in April 2012, when this oxypleth rose from $80 \mathrm{~m}$ near the Gulf to $\sim 40 \mathrm{~m}$ depth off Cabo Corrientes. The $4.4 \mu \mathrm{mol} / \mathrm{kg}$ oxypleth ranged from $\sim 90$ to $\sim 300 \mathrm{~m}$ depth in all cruises, except in April 2012, when this was elevated to $50 \mathrm{~m}$ depth off Cabo Corrientes.

Stronger geographic variability in the salinity values were observed in the first $100 \mathrm{~m}$ depth of the water column (Figure 6), where Gulf of California Water (GCW, >35.1 g/kg), Transitional Water (TW), and Tropical Surface Water (TSW, <34.6 g/kg) converge. In February 2010, GCW was recorded in the mouth of the Gulf, TSW was found from the Islas Marias to north of Cabo Corrientes, and TW ( $>34.6$ and $<31 \mathrm{~g} / \mathrm{kg}$ ) between these. In April 2012, most of the transect was occupied by GCW, decreasing in depth from the mouth of the Gulf to Cabo Corrientes. TSW was absent in this period. In the other three cruises, June 2015, March 2016, and October 2017, TSW was extended to the north, mainly in June 2015, when it was detected near the mouth of the Gulf. Below the surface water masses, TW and Subtropical Subsurface Water (StSsW) occurred.

Geographically, the temperature values also showed vertical gradients in the first $100 \mathrm{~m}$ of the water column (Figure 7). The mixed layer depth fluctuated between 30 and $50 \mathrm{~m}$ in most of the cruises, but it was shallowest $\sim 20 \mathrm{~m}$ and deepest $\sim 80 \mathrm{~m}$ off Cabo Corrientes in April $2012\left(\sim 20\right.$ and $\left.24{ }^{\circ} \mathrm{C}\right)$ and June $2015\left(\sim 26\right.$ and $\left.30{ }^{\circ} \mathrm{C}\right)$, respectively. The thermocline depth followed a similar tendency to the mixed layer in all periods, being shallowest in April 2012 ( 30 m) and deepest in June 2015 (>100 m) off Cabo Corrientes. 


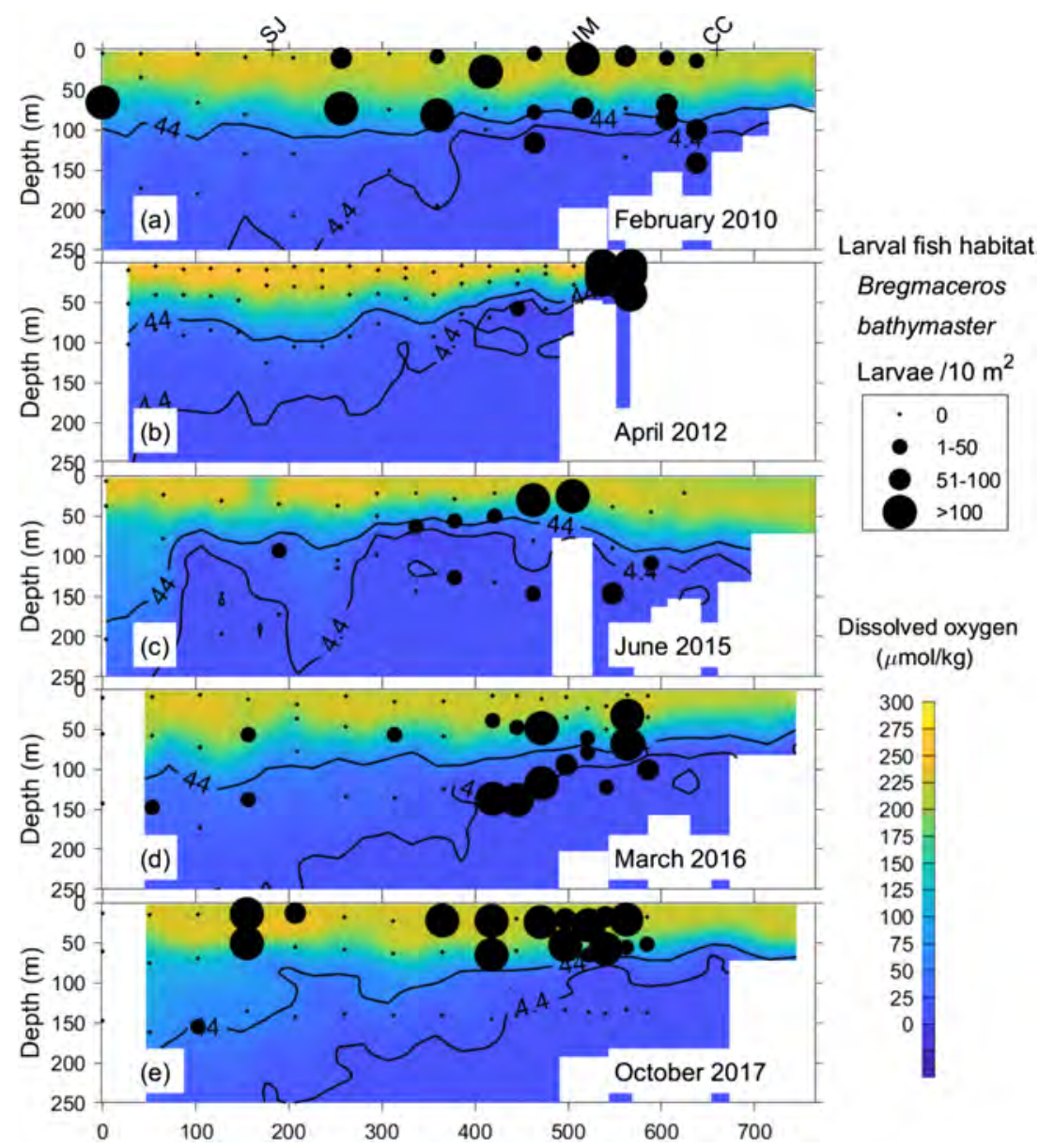

Figure 5. Dissolved oxygen concentration (color) and larval fish habitat Bregamceros bathymaster (black circles) in the northern limit of the shallow oxygen minimum zone of the tropical-subtropical convergence of the northeastern Pacific Ocean. The 44 and $4.4 \mu \mathrm{mol} / \mathrm{kg}$ oxipleths are marked (black lines). The $x$ axis represents distance $(\mathrm{km})$ from the first station in the Gulf of California entrance along the transect shown in Figure $1 \mathrm{~b}$.

\subsection{Geographic Distribution of Larval Fish Habitats}

The total mean larval abundance and the specific richness showed strong variability among the cruises (Table 3). Nevertheless, the Bray-Curtis dissimilarity index defined three groups of samples or larval fish habitats in each cruise analyzed to a cut of $\sim 20 \%$ of information remaining of the data set (not shown), which were significantly different (analysis of similarities: $R=0.5, p<0.001$ ) in the five cruises. Based on the exploration of the indicator species of each habitat (Table 3) and their geographical location (Figures 5-7), two of the three larval fish habitats were recurrent but with changes in their distribution in response to environmental events.

A recurrent larval fish habitat (LFH 1) was observed mainly around the Islas Marias to north off Cabo Corrientes, extending to the north but in lower abundance and frequency. In April 2012 this habitat was concentrated only around the Islas Marias (Figure 5). Vertically, this habitat, although it was found throughout the observed water column $(0-250 \mathrm{~m})$, showed high abundance and frequency below the oxycline in oxygen concentrations $<44 \mu \mathrm{mol} / \mathrm{kg}$, mainly in June 2015 and March 2016. This habitat had high mean larval abundance and specific richness in February 2010 but had the highest specific richness in October 2017 and the lowest mean larval abundance of the habitats in most of the cruises (June 2015, March 2016, and October 2017) (Table 3). Bregmaceros bathymaster was the indicator species of the habitat according to the Phi coefficient during the five cruises (Table 3). Etropus crossotus and Caranx caballus larvae were also indicator species, but in only three of the five cruises. 


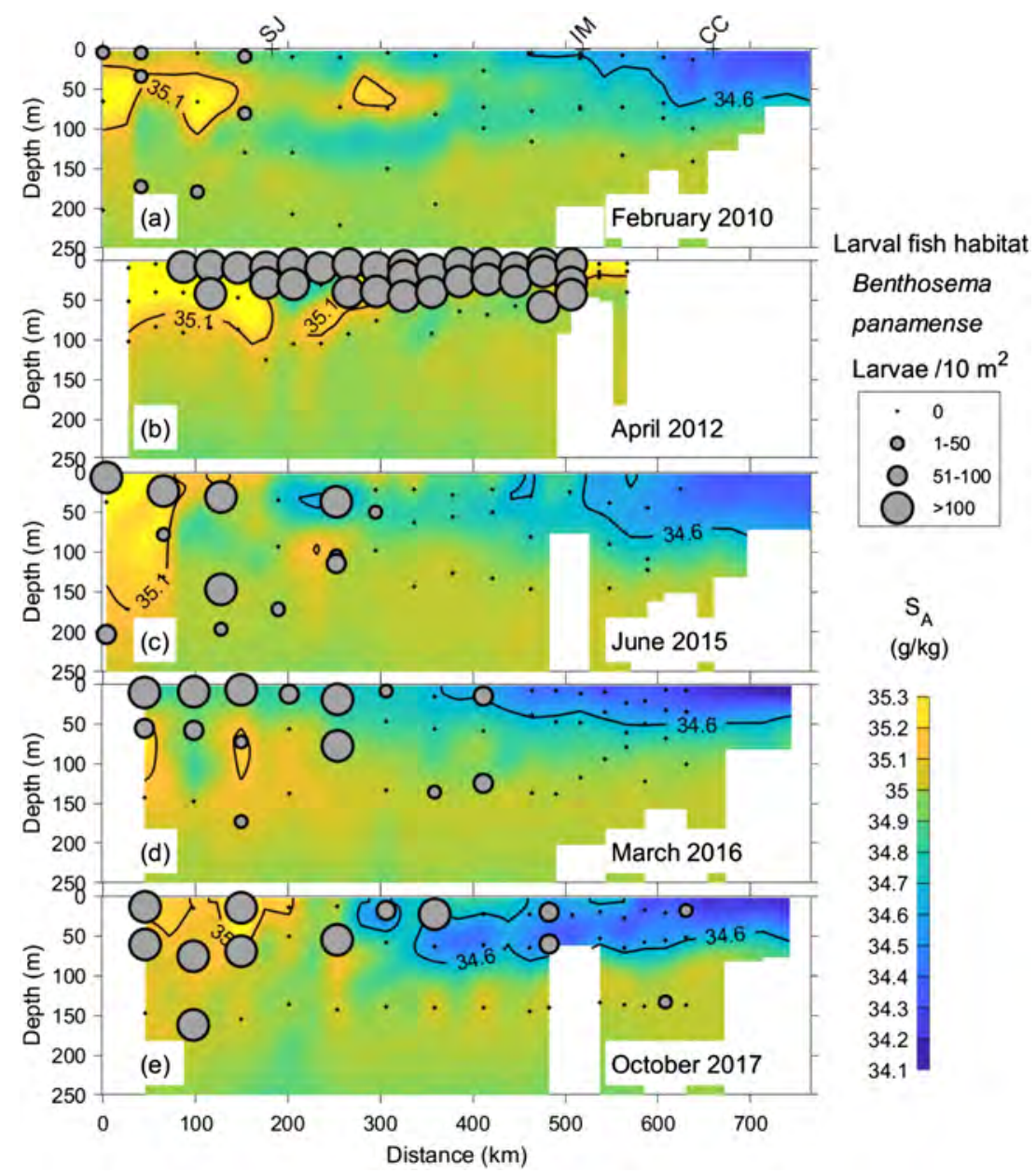

Figure 6. Salinity (color) and larval fish habitat Benthosema panamense (gray circles) in the northern limit of the shallow oxygen minimum zone of the tropical-subtropical convergence of the northeastern Pacific Ocean. The 34.6 and $35.1 \mathrm{~g} / \mathrm{kg}$ isohalines are marked (black lines) as they are the indicators of Tropical Surface Water and Gulf of California Water. The $x$ axis represents distance $(\mathrm{km})$ from the first station in the Gulf of California entrance along the transect shown in Figure 1b.

The second recurrent larval fish habitat (LFH-2) was located mainly in the mouth of the Gulf of California, extending to the south in April 2012 and October 2017 (Figure 6). It was observed vertically throughout the sampled water column but with greater abundance from the oxycline to the surface $(>44 \mu \mathrm{mol} / \mathrm{kg})$, although in April 2012 this habitat was concentrated only in the oxygenated layer. Its mean larval abundance and its species richness were the highest in April 2012 and October 2017, and both biological descriptors were relatively high in June 2015 and March 2016 (Table 3). Benthosema panamense was the indicator species of the habitat, except in October 2017, where other indicator species of the habitat, Vinciguerria lucetia and Lampanyctus parvicauda, were recorded (Table 4).

A larval fish habitat (LFH-3) located mainly under the oxycline along the transect was detected in February 2010, April 2012, and October 2017 (Figure 7). This habitat had relatively low larval abundance and the lowest specific richness (Table 3). Diogenichthys laternatus was the indicator species of this habitat during the three cruises (Table 3). In June 2015 and March 2016, another larval fish habitat (LFH-4) occurred mainly from the oxycline to the surface near Islas Marias (Figure 7), with Auxis spp. as the indicator species, together with Paranthias colonus and Syacium ovale (Table 3).

\subsection{Environmental Variables and Larval Fish Habitats}

In the redundancy canonical analysis, environmental variables account for $12.8 \%$ of the total variance, and the first two canonical axes explain $12 \%$ of the variance (Figure 8 and Table 4 ). The first canonical axis was 


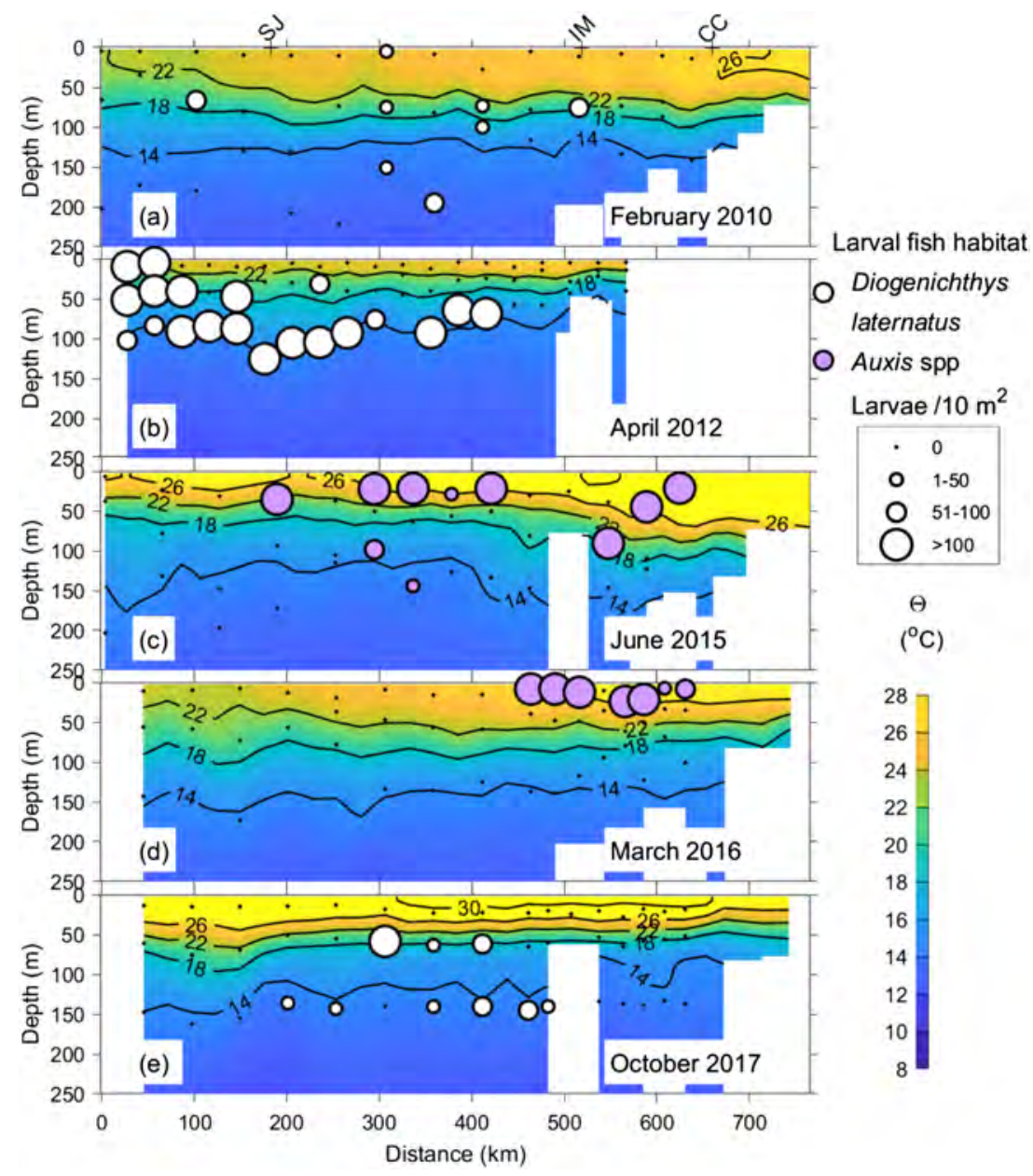

Figure 7. Conservative temperature (color) and larval fish habitats Diogenichthys laternatus (white circles) and Auxis spp. (purple circles) in the northern limit of the shallow oxygen minimum zone of the tropical-subtropical convergence of the northeastern Pacific Ocean. The $x$ axis represents distance $(\mathrm{km})$ from the first station in the Gulf of California entrance along the transect shown in Figure $1 \mathrm{~b}$.

related to horizontal gradients, in which salinity was the more correlated variable $(r=0.4)$. The second canonical axis was related to vertical gradients, where temperature $(r=0.5)$ and the dissolved oxygen $(r=0.4)$ were the variables with stronger correlations.

The ordination of the recurrent larval fish habitats showed a preference to specific environmental conditions. The LFH-1 observed around the Islas Marias indicated by B. bathymaster (black circles) was inversely correlated with the salinity and the dissolved oxygen, while the LFH-2 indicated by B. panamense detected near the Gulf of California (gray circles) was correlated with high values of temperature, salinity, and dissolved oxygen (Figure 8).

The less recurrent larval fish habitats also showed a relationship with the environmental conditions. The LFH-3, dominated by D. laternatus under the oxycline in February 2010, April 2012, and October 2017 (white circles), was inversely correlated with temperature and dissolved oxygen. Also, the LFH-4, dominated by Auxis spp. associated with the warm surface layer in June 2015 and March 2016 (purple circles), was correlated with high temperature and low salinity (Figure 8).

In addition, the indicator species of each habitat overlaid on $\Theta-S_{A}$ diagrams (Figure 9) showed different affinities to the water masses. Although B. bathymaster (LFH-1) and B panamense (LFH-2) indicator species of recurrent habitats were widely distributed among the water masses, $B$. bathysmater was more frequent in TSW in relation to $B$. panamense, and this last species was more frequent in GCW. In contrast, $D$. 
Table 3

Species Indicators for Each of the Larval Fish Habitat (LFH) Determined by the Indicator Species Analysis in the Northern Limit of the Shallow Oxygen Minimum Zone off México.

\begin{tabular}{|c|c|c|c|c|c|c|c|c|c|c|c|c|c|c|c|}
\hline \multirow[b]{2}{*}{ Species } & \multicolumn{3}{|c|}{ February 2010} & \multicolumn{3}{|c|}{ April 2012} & \multicolumn{3}{|c|}{ June 2015} & \multicolumn{3}{|c|}{ March 2016} & \multicolumn{3}{|c|}{ October 2017} \\
\hline & LFH-1 & LFH-2 & LFH-3 & LFH-1 & LFH-2 & LFH-3 & LFH-1 & LFH-2 & LFH-4 & LFH-1 & LFH-2 & LFH-4 & LFH-1 & LFH-2 & LFH-3 \\
\hline $\begin{array}{l}\text { Bregmaceros } \\
\text { bathymaster }\end{array}$ & 0.62 & & & 0.42 & & & 0.47 & & & 0.51 & & & 0.71 & & \\
\hline Etropus crossotus & 0.33 & & & 0.63 & & & & & & & & & 0.41 & & \\
\hline Caranx caballus & 0.33 & & & & & & 0.17 & & & 0.21 & & & & & \\
\hline $\begin{array}{l}\text { Benthosema } \\
\text { panamense }\end{array}$ & & 0.51 & & & 0.64 & & & 0.70 & & & 0.52 & & 0.57 & & \\
\hline Vinciguerria lucetia & & & 0.14 & & 0.27 & & & 0.44 & & & 0.36 & & & 0.26 & \\
\hline $\begin{array}{r}\text { Lampanyctus } \\
\text { parvicauda }\end{array}$ & & & & & 0.61 & & & 0.23 & & & & & & 0.48 & \\
\hline $\begin{array}{c}\text { Diogenichthys } \\
\text { laternatus }\end{array}$ & & & 0.52 & & & 0.63 & & 0.68 & & 0.20 & & & & & 0.38 \\
\hline Auxis spp & & & & & 0.40 & & & & 0.32 & & & 0.92 & 0.35 & & \\
\hline Paranthias colonus & & & & & & & & & 0.18 & & & 0.58 & & & \\
\hline Syacium ovale & & & 0.23 & & & & & & 0.85 & & & 0.57 & 0.31 & & \\
\hline Specific richness & 17 & 10 & 10 & 10 & 21 & 15 & 10 & 17 & 21 & 12 & 15 & 19 & 37 & 36 & 12 \\
\hline Samples & 18 & 7 & 8 & 6 & 30 & 21 & 10 & 12 & 10 & 17 & 14 & 7 & 17 & 13 & 9 \\
\hline Average abundance & 75 & 29 & 40 & 725 & 1919 & 458 & 61 & 302 & 385 & 83 & 177 & 249 & 143 & 288 & 52 \\
\hline
\end{tabular}

laternatus (LFH-3) and Auxis spp. (LFH-4) showed a clear affinity to a different water mass. D. laternatus was concentrated in StSsW and Auxis spp. in TW.

\section{Discussion}

\subsection{Temporal Changes in Dissolved Oxygen Concentrations}

In the context of the deoxygenation of the oceans, the dissolved oxygen series from cruises (2000 to 2017) that covered the northern limit of the shallow OMZ off Mexico suggested a vertical expansion of suboxic water $(<4.4 \mu \mathrm{mol} / \mathrm{kg})$ in the present century (Figure 3). As in previous studies on the shallow OMZs (e.g., Schmidtko et al., 2017; Stramma et al., 2008; Stramma et al., 2010), the databases used were temporally and spatially irregular. The deoxygenation trend is evident despite the high mesoscale activity modulated by seasonality and interannuality in this region of the Pacific Ocean off Mexico (Godínez et al., 2010a; Kurczyn et al., 2012).

The vertical expansion of the suboxic water $(<4.4 \mu \mathrm{mol} / \mathrm{kg}$ oxypleth) over time shown in this study (Figure 3 ) is an indicator of the progress of the deoxygenation in the shallow OMZ off Mexico, but many details of its development remain unknown. In the northern limit of the shallow OMZ off Mexico, the strong stratification characteristic of the water column (Godínez et al., 2010a; Davies et al., 2015; Portela et al., 2016) may be limiting the expansion of the hypoxic water ( $<44 \mu \mathrm{mol} / \mathrm{kg}$ oxypleth) to the sea surface, that is, the oxy-

Table 4

Eigenvalues and Explained Variation of the Explanatory Variables and Correlations Among Environmental Variables and Ordination Axes by the Canonical Correspondence Analysis

\begin{tabular}{lccc}
\hline Variable & Axis 1 & .Axis 2 & Axis 3 \\
\hline Statistics & & & \\
Eigenvalue & 0.0846 & 0.035 & 0.0082 \\
Explained variation (cumulative) & 8.46 & 11.95 & 12.78 \\
Pseudo-canonical correlation & 0.6341 & 0.5635 & 0.3979 \\
Explained fitted variation (cumulative) & 66.18 & 93.55 & 100 \\
Correlation variable & & & \\
Conservative temperature $(\Theta)$ & 0.0284 & 0.5176 & 0.1564 \\
Absolute salinity $\left(S_{A}, \mathrm{~g} / \mathrm{kg}\right)$ & 0.3944 & 0.0051 & -0.3116 \\
Dissolved oxygen $(\mu \mathrm{mol} / \mathrm{kg})$ & 0.303 & 0.4085 & 0.1974 \\
\hline
\end{tabular}

cline. However, the suboxic water is raised to depths near to the lower limit of oxycline ( $44 \mu \mathrm{mol} / \mathrm{kg}$ oxypleth), particularly in the zone south of Cabo Corrientes (Figure 5). This trend demonstrates that the hypoxic layer (from $\sim 4.4$ to $44 \mu \mathrm{mol} / \mathrm{kg}$ oxypleths) has been thinning through time (Figure 3). The implications could be drastic for zooplankton species that live under hypoxic conditions and species that migrate between the oxycline and the hypoxic layer for feeding and to avoid depredation (Davies et al., 2015; Koslow et al., 2011; Kreiner et al., 2009; Sánchez-Velasco et al., 2017). Most of these species live near their physiological limits, similar to the deep ( 400 m) copepod species reported by Wishner et al. (2018). In addition, in this study the temperature values at the depth of the oxycline did not show significant changes over time, but the temperature at the depth of the $4.4 \mu \mathrm{mol} / \mathrm{kg}$ oxypleth showed some significant increase due to the ascent of that oxypleth (Figure 3), which may be a major 


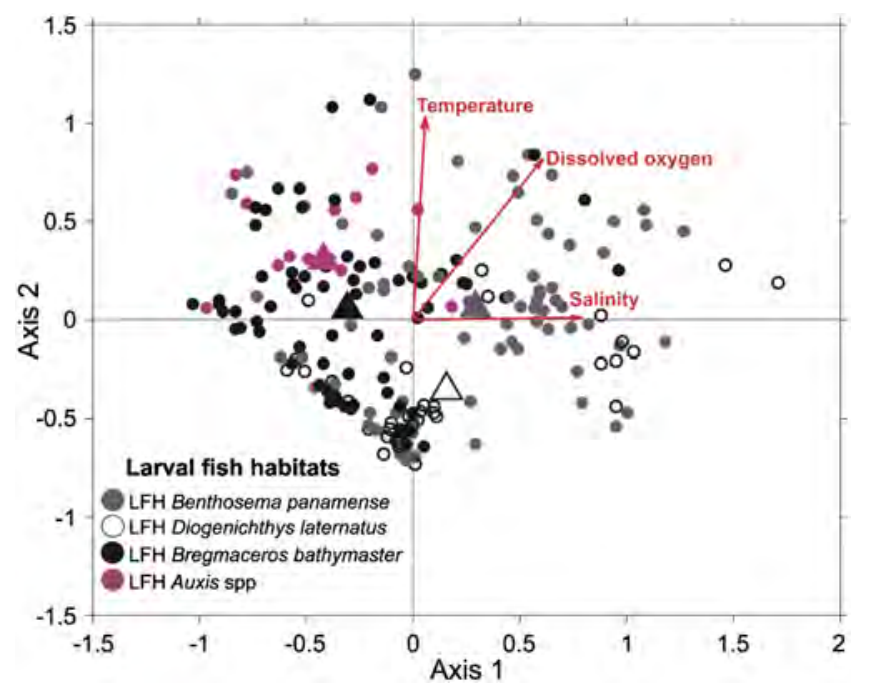

Figure 8. Biplot of the canonical correspondence analysis conducted for fish larvae and environmental variables in the northern limit of the oxygen minimum zone of the tropical-subtropical convergence of the northeastern Pacific Ocean. Triangles indicate the centroid of each larval fish habitat. Larval fish habitats are color coded as in Figures 4-6. stress for the organisms. The shallowing of the $4.4 \mu \mathrm{mol} / \mathrm{kg}$ oxypleth, besides reducing the hypoxic layer, also exposes the organisms to warmer temperatures and less saline conditions, which may impact the physiology and behavior of the organisms (Deutch et al. 2015). These environmental changes may also increase the stress and mortality rate of some diel vertical migrators that are physiologically limited by suboxic conditions.

Relationships between ocean warming and deoxygenation are complex and indirect. Authors like Cheng et al. (2015) analyzed a global-averaged ocean temperature trend, observed that even though the ocean has continued to gain heat in this century (XXI), the pattern of change is different in the interior ocean. The sea surface layer (1-100 m depth) temperature has decreased in the recent years, accompanied by heating in the 101-300 $\mathrm{m}$ layer as a result of changes in the frequency of the warm and cold ENSO phases. In addition, the subsurface ocean from 301 to 700 $m$ experienced a cooling, which Cheng et al. (2015) indicates is "another instance of variability in the natural ocean." In the shallow OMZ off Mexico, the hypoxic layer and upper limit of the suboxic layer fall between 101 and $300 \mathrm{~m}$ depth, corresponding with the layer that is warming according to Cheng et al. (2015). The heating of this critical layer could be a trigger of the deoxygenation and loss of the hypoxic habitats for many marine organisms.

Our results are consistent with the global tendencies of deoxygenation and expansion of the shallow OMZs (Bograd et al., 2008; Schmidtko et al., 2017; Stramma et al., 2008; Stramma et al., 2010), but the processes that generate this deoxygenation remain uncertain. It is therefore difficult to predict how deoxygenation effects will proceed in this region. Authors like Meier et al. (2018) reported that the changes in dissolved oxygen in the deep waters of the Baltic Sea are primarily caused by the increase of organic matter. In studies based on physical data, thermal stratification has been identified as the main cause of the deoxygenation in the ocean (Schmidtko et al., 2017). Other research groups (Duteil et al., 2018) pointed out that the phase changes of the PDO relate to the dissolved oxygen concentration. Positive PDO conditions explain a significant part of the current deoxygenation occurring in the eastern Pacific Ocean (Breitburg et al., 2018). However, Brewer (2018) mentioned that there are clearly multiple processes at work on the deoxygenation in the oceans that could only be explained by multidisciplinary studies focused on global ocean-atmosphere interconnections. Multidisciplinary studies and the maintenance of long time series must be priorities for the understanding of the varied response of marine life to the deoxygenation and warming of the oceans.

\subsection{Geographic Variability of Larval Fish Habitats and Water Masses}

The distribution of the larval fish habitats defined in this study was related to the dissolved oxygen gradients and the water masses that converge in the Pacific Ocean off Mexico. Despite the inherent seasonal and interannual variations in the zooplankton samples that support this study, recurrent larval fish habitats were defined, but with changes in their distribution clearly linked to the ENSO phases (Figures 5-7).

The recurrence of the LFH-1 indicated by B. bathymater and LFH-2 indicated by B. panamense showed that their components were tolerant to environmental changes; that is, these species had a wide environment window defined by strong gradients of dissolved oxygen, temperature, and salinity. However, the LFH-1 was mostly located off Cabo Corrientes associated with highly oxygenated TSW, and with StSsW, characterized by low oxygen concentrations, while the LFH-2 was detected to be mostly associated with GCW, water with high dissolved oxygen (Figure 9). Conversely, the LFH-3 indicated by D. laternatus and LFH-4 indicated by Auxis spp. showed that their components inhabited a reduced environmental window, where the LFH-3 had high affinity with StSsW and the LFH-4 with TSW (Figure 9).

The influence of ENSO phases in the region was evident in the larval fish habitats with a reduced environmental window. During the warm phase of the ENSO (June 2015 and March 2016), the LFH-3 of a more southern origin and immersed in TSW (Figure 9) replaced the LFH-4 during two different warm seasons, showing that its presence in the study area was not random (Figure 7). The presence of the LFH-4 in the 
(a) LFH Bregmaceros bathymaster

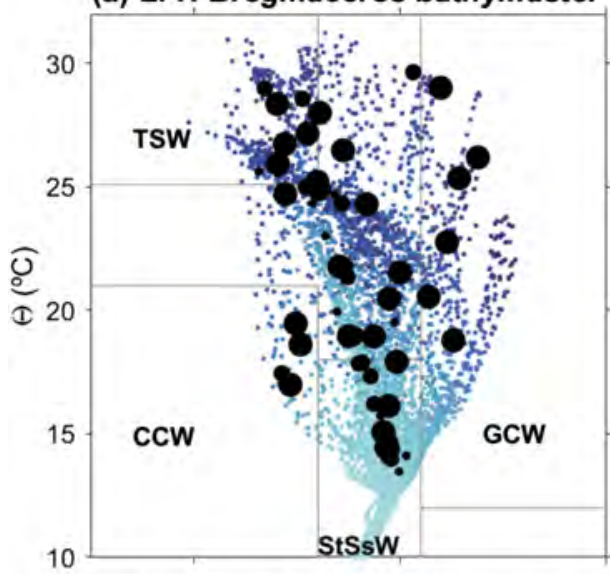

(c) LFH Diogenichthys laternatus

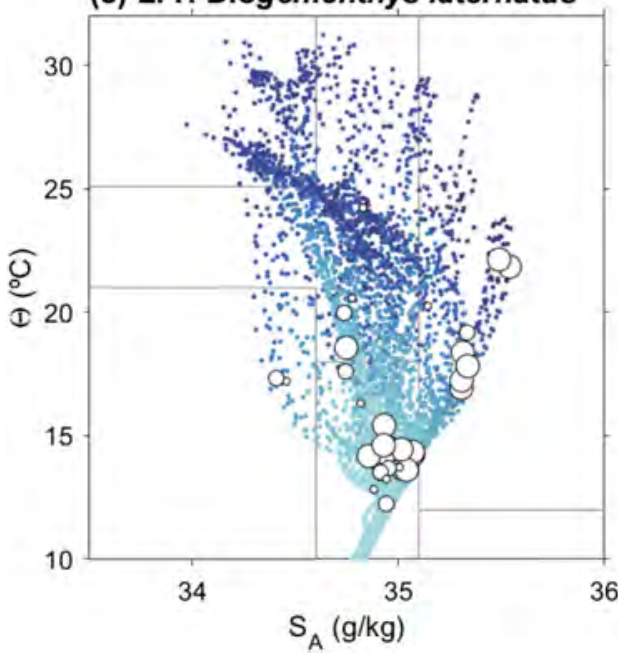

(b) LFH Benthosema panamense

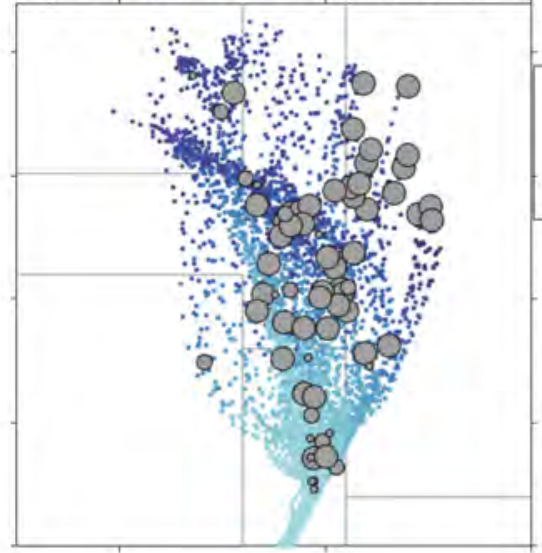

(d) LFH Auxis spp

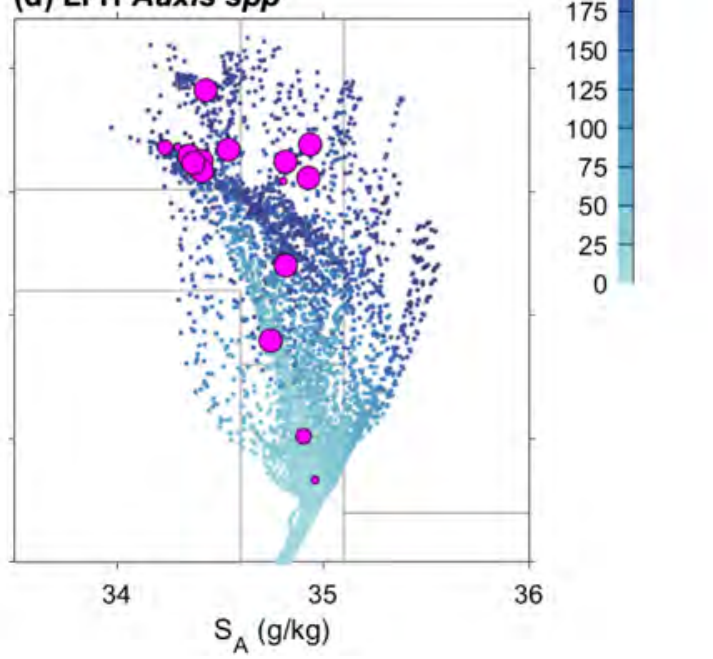

Figure 9. $\Theta-S_{A}$ diagrams with larval fish habitats Bregmaceros bathymaster (black circles), Benthosema panamense (gray circles), Diogenichtys laternatus (white circles), and Auxis spp. (purple circles) of the northern limit of the shallow oxygen minimum zone of the tropical-subtropical convergence of the northeastern Pacific Ocean. Water masses are Tropical Surface Water (TSW), Gulf of California Water (GCW), California Current Water (CCW), and Subtropical Subsurface Water (StSsW), according to Portela et al. (2016). Dissolved oxygen is shown in color.

region also modified the distribution of the recurrent habitats. The LFH-4 displaced the LFH-1 to a greater depth, and the LFH-2 to further north in both warm periods. In contrast, during the cold phase of the ENSO (April 2012), the LFH-2 was extended along the oxycline further south into GCW, and the LFH-1 was concentrated in the Islas Marias region. Besides, the LFH-3 was elevated close to the oxycline in water with low oxygen concentrations (Figures 5-7).

The recurrence of larval fish habitats with high abundance in different seasons and ENSO phases shows their resilience to the environment in the context of deoxygenation. Previous studies (Gallo \& Levin, 2016; Koslow et al., 2011) have reported that dissolved oxygen concentrations in the OMZs are lower than lethal concentrations determined for many fish species in the laboratory. However, OMZs are not devoid of fish. Therefore, the results of this study support the idea that some fish species (i.e., B. bathymaster, D. laternatus, and B. panamense), from early phases to adult stages, have developed evolutionary physiological adaptations to strong dissolved oxygen gradients and to seasonal and interannual changes in the characteristics of the shallow OMZ off Mexico. These results are similar to descriptions for demersal fish species in the Gulf of California that are also adapted to live under the extremely low oxygen conditions characteristic of the Gulf of California OMZ (Gallo et al., 2019). 
Previous studies have reported that the fish can respond to changes in oxygen over a range of time scales from rapid (hours to days) changes in gene expression (Gracey \& Somero, 2001, Tiedke et al., 2014) to longer time scales through changes in the presence and density of specific species leading to altered community structures (Chu \& Tunnicliffe, 2015; Keller et al., 2015). It can be expected that if deoxygenation continues, the frequency and abundance of species adapted to low thresholds of dissolved oxygen, including specific mesopelagic species examined in this study, will increase. Continuous monitoring is strongly recommended in the context of climatic change and deoxygenation.

\section{Conclusion}

Based on a series of 19 oceanographic cruises (1,515 profiles) between 2000 and 2017 made in the northern limit of the shallow OMZ off Mexico, a significant vertical expansion of the upper limit of suboxic conditions $(<4.4 \mu \mathrm{mol} / \mathrm{kg}$ ) was detected. In this context, one recurrent larval fish habitat (indicated by B. bathymaster larvae) extended throughout the water column off Cabo Corrientes from StSsW (suboxic conditions) to the surface $(220 \mu \mathrm{mol} / \mathrm{kg})$. The second recurrent larval fish habitat (B. panamense) was located between the oxycline $(>44 \mu \mathrm{mol} / \mathrm{kg}$ ) and the surface in association with GCW. During the warm El Niño event of 2015-2016, a tropical larval fish habitat (Auxis spp.) associated with TW appeared to change the larval habitat distributions. These results indicate that some species are resilient to changes of dissolved oxygen and temperature generated by both intermittent events (ENSO phases) and continuing processes (deoxygenation). However, other groups of species, with reduced environmental windows, could be affected by deoxygenation and warming associated, as well others variables not considered here.

\section{Acknowledgments}

This work was made possible thanks to the financial support of SEP-CONACyT (contract 2014-236864, L. S. V.) and Fronteras de la Ciencia-CONACyT (contract 2015-2-280, L. S.V.). The hydrographic and biological data used for this paper are available on request by writing to L. S. V. (lsvelasc@gmail. com) and at https:doi.org/10.5281/ zenodo.3479794. We thank the scientific and technical staff who took part in the cruises aboard R/V Francisco de Ulloa and Alpha Helix. Special thanks to LEGOZ (Virtual Laboratory of Ecology, Genetic, Oceanography and Zooplankton) of CICIMAR-IPN. L. S. V. would like to thank Instituto Politécnico Nacional and CONACyT for their support during her sabbatical. Special thanks to Natalya Gallo and Andrew Thompson and the anonymous reviewer for their important suggestions.

\section{References}

Agresti, A. (2015). Foundations of linear and generalized linear models. Wiley series in probability and statistics (p. 444). USA: Hoboken.

Apango-Figueroa, E., Sánchez-Velasco, L., Lavín, M. F., Godínez, V. M., \& Barton, E. D. (2015). Larval fish habitats in a mesoscale dipole eddy in the Gulf of California. Deep Sea Res. Part I Oceanogr. Res. Pap., 103, 1-12. https://doi.org/https://doi.org/10.1016/j. dsr.2015.05.005

Atwood, E., Duffy-Anderson, J. T., Horne, J. K., \& Ladd, C. (2010). Influence of mesoscale eddies on ichthyoplankton assemblages in the Gulf of Alaska. Fisheries Oceanography, 19, 493-507. https://doi.org/10.1111/j.1365-2419.2010.00559.x

Bazzino, G., Gilly, W. F., Markaida, U., Salinas-Zavala, C. A., \& Ramos-Castillejos, J. (2010). Horizontal movements, vertical-habitat utilization and diet of the jumbo squid (Dosidicus gigas) in the Pacific Ocean off Baja California Sur, Mexico. Progress in Oceanography, 86(1), 59-71. https://doi.org/10.1016/j.pocean.2010.04.017

Beers, J. R. (1976). Determination of zooplankton biomass. In H. F. Steedman (Ed.), Zooplankton fixation and preservation (pp. 35-84). Paris: UNESCO.

Bograd, S. J., Castro, C. G., Di Lorenzo, E., Palacios, D. M., Bailey, H., Gilly, W., \& Chavez, F. P. (2008). Oxygen declines and the shoaling of the hypoxic boundary in the California Current. Geophysical Research Letters, 35, L126076. https://doi.org/10.1029/ 2008GL034185

Breitburg, D., Levin, L.A., Oschlies, A., Grégoire, M., Chavez, F.P., Conley, D.J., et al., 2018. Declining oxygen in the global ocean and coastal waters. Science (80-.). 359, eaam7240. https://doi.org/10.1126/SCIENCE.AAM7240

Brewer, P. (2018). Multiple choices exist for changing ocean oxygen concentrations. Eos (Washington. DC)., 99. https://doi.org/10.1029/ 2018EO098367

Brewer, P. G., \& Peltzer, E. T. (2016). Ocean chemistry, ocean warming, and emerging hypoxia: Commentary. Journal of Geophysical Research: Oceans, 121, 3659-3667. https://doi.org/10.1002/2016JC011651

Cavole, L. M., Demko, A. M., Diner, R. E., Giddings, A., Koester, I., Pagniello, C. M. L. S., et al. (2016). Biological impacts of the 2013-2015 warm-water anomaly in the northeast Pacific: Winners, losers, and the future. Oceanography, 29, 273-285. https://doi.org/https://doi. org/10.5670/oceanog.2016.32

Cepeda-Morales, J., Gaxiola-Castro, G., Beier, E., \& Godínez, V. M. (2013). The mechanisms involved in defining the northern boundary of the shallow oxygen minimum zone in the eastern tropical Pacific Ocean off Mexico. Deep. Res. Part I Oceanogr. Res. Pap., 76, 1-12. https://doi.org/10.1016/j.dsr.2013.02.004

Chavez, F. P., \& Messié, M. (2009). A comparison of Eastern Boundary Upwelling Ecosystems. Progress in Oceanography, 83(1-4), 80-96. https://doi.org/10.1016/j.pocean.2009.07.032

Cheng, L., Zheng, F., \& Zhu, J. (2015). Distinctive ocean interior changes during the recent warming slowdown. Scientific Reports, 5, 14346. https://doi.org/10.1038/srep14346

Chu, J. W. F., \& Tunnicliffe, V. (2015). Oxygen limitations on marine animal distributions and the collapse of epibenthic community structure during shoaling hypoxia. Global Change Biology, 21(8), 2989-3004. https://doi.org/10.1111/gcb.12898

Clarke, K. R., \& Ainsworth, M. (1993). A method of linking multivariate community structure to environmental variables. Mar. Ecol. Ser., $92,205$.

Clarke, K. R., \& Green, R. H. (1988). Statistical design and analysis for a 'biological effects' study. Mar. Ecol. Ser., 46, $213-226$.

Contreras-Catala, F., Sánchez-Velasco, L., Beier, E., Godínez, V. M., Barton, E. D., \& Santamaría-del-Angel, E. (2016). Effects of geostrophic kinetic energy on the distribution of mesopelagic fish larvae in the southern Gulf of California in summer/fall stratified seasons. PLoS ONE, 11(10), e0164900. https://doi.org/10.1371/journal.pone.0164900

Costello, M. J. (2009). Distinguishing marine habitat classification concepts for ecological data management. Marine Ecology Progress Series, 397, 253-268. https://doi.org/10.3354/meps08317 
Davies, S. M., Sánchez-Velasco, L., Beier, E., Godínez, V. M., Barton, E. D., \& Tamayo, A. (2015). Three-dimensional distribution of larval fish habitats in the shallow oxygen minimum zone in the eastern tropical Pacific Ocean off Mexico. Deep Sea Res. Part I Oceanogr. Res. Pap., 101, 118-129. https://doi.org/https://doi.org/10.1016/j.dsr.2015.04.003

Diaz, R. J., \& Rosenberg, R. (2008). Spreading dead zones and consequences for marine ecosystems. Science (80), 321, $926-929$.

Doyle, M. J., Morse, W. W., \& Kendall, A. W. (1993). A comparison of larval fish assemblages in the temperate zone of the northeast Pacific and northwest Atlantic Oceans. Bulletin of Marine Science, 53, 588-644.

Duteil, O., Oschlies, A., \& Böning, C. W. (2018). Pacific Decadal Oscillation and recent oxygen decline in the eastern tropical Pacific Ocean. Biogeosciences, 15, 7111-7126.

Ekau, W., Auel, H., P̈ortner, H. O., \& Gilbert, D. (2010). Impacts of hypoxia on the structure and processes in pelagic communities (zooplankton, macro-invertebrates and fish). Biogeosciences, 7(5), 1669-1699. https://doi.org/10.5194/bg-7-1669-2010

Ekau, W., \& Verheye, H. M. (2005). Influence of oceanographic fronts and low oxygen on the distribution of ichthyoplankton in the Benquela and southern Angola currents. African Journal of Marine Science, 27(3), 629-639. https://doi.org/10.2989/18142320509504123

Escribano, R., Hidalgo, P., \& Krautz, C. (2009). Zooplankton associated with the oxygen minimum zone system in the northern upwelling region of Chile during March 2000. Deep Sea Research, Part II, 56, 1083-1094. https://doi.org/10.1016/j.dsr2.2008.09.009

Fernandez-Alamo, M. A., \& Farber-Lorda, J. (2006). Zooplankton and the oceanography of the eastern tropical Pacific: A review. Progress in Oceanography, 69, 318-359. https://doi.org/10.1016/j.pocean.2006.03.008

Fiedler, P. C., \& Talley, L. D. (2006). Hydrography of the eastern tropical Pacific: A review. Progress in Oceanography, 69(2-4), 143-180. https://doi.org/10.1016/j.pocean.2006.03.008

Field, J. G., Clarke, K. R., \& Warwick, R. M. (1982). A practical strategy for analyzing multispecies distribution patterns. Marine Ecology Progress Series, 8, 37-52.

Gallo, N. D., \& Levin, L. A. (2016). Fish ecology and evolution in the world's oxygen minimum zones and implications of ocean deoxygenation, 1st ed. Elsevier Ltd: Advances in marine biology. https://doi.org/10.1016/bs.amb.2016.04.001

Gallo, N. D., Levin, L. A., Beckwith, M., \& Barry, J. P. (2019). Home sweet suboxic home: Remarkable hypoxia tolerance in two demersal fish species in the Gulf of California. Ecology, 100(3), e02539. https://doi.org/10.1002/ecy.2539

Godínez, V. M., Beier, E., Sánchez Velasco, L., \& Santamaría-del-Angel, E. (2015). Datos Hidrográficos en la región sur y boca exterior del Golfo de California: Campaña GLIDER-MARIAS 1506 (3 al 16 de junio del 2015). In CICESE Technical Report 19284 (103 pp.). CICESE: Departamento de Oceanografía Física.

Godínez, V. M., Lavín, M. F., Sánchez Velasco, L., \& Cabrera Ramos, C. E. (2012). Datos Hidrográficos en el Golfo de California: Campaña GOLCA-1204 (26 de abril al 4 de mayo del 2012). In CICESE Technical Report 104573 (89 pp.). CICESE: Departamento de Oceanografía Física.

Godínez, V. M., Sánchez Velasco, L., Beier, E., \& Santamaría-del-Angel, E. (2016). Datos Hidrográficos en la región sur y boca exterior del Golfo de California: Campaña MARIAS 1603 (2 al 8 de marzo del 2016). In CICESE Technical Report 20783 (66 pp.). CICESE: Departamento de Oceanografía Física.

Godínez, V. M., Sánchez-Velasco, L., Beier, E., \& Santamaría-del-Angel, E. (2017). Datos hidrográficos en la región sur y boca exterior del Golfo de California: campaña MARIAS 1609 (14 al 23 de septiembre del 2016). In CICESE Technical Report 22443 (82 pp.). CICESE: Departamento de Oceanografía Física.

Godínez, V. M., Beier, E., Lavín, M. F., \& Kurczyn, J. A. (2010). Circulation at the entrance of the Gulf of California from satellite altimeter and hydrographic observations. Journal of Geophysical Research, Oceans, 115. https://doi.org/10.1029/2009JC005705

Godínez, V. M., Beier, E., Sánchez Velasco, L., Lavín, M. F., \& Cabrera Ramos, C. E. (2010). Datos Hidrográficos en la región sur del Golfo de California: Campaña CONABIO 1002 (14 al 27 de febrero del 2010) (Vol. 108, p. 99751). CICESE: Departamento de Oceanografía Física.

Gracey, A. Y., Troll, J. V, Somero, G. N. (2001). Hypoxia-induced gene expression profiling in the euryoxic fish Gillichthys mirabilis. Proceedings of the National Academy of Sciences, 98, 1993 LP - 1998. https://doi.org/10.1073/pnas.98.4.1993

Green-Ruiz, Y. A., \& Hinojosa-Corona, A. (1997). Study of the spawning area of the Northern anchovy in the Gulf of California from 1990 to 1994, using satellite images of sea surface temperatures. Journal of Plankton Research, 19, 957-968. https://doi.org/10.1093/plankt/ 19.8.957

Hammann, M. G., \& Cisneros-Mata, M. A. (1989). Range extension and commercial capture of the northern anchovy, Engraulis mordax Girard, in the Gulf of California, Mexico. California Fish \& Game.

Hirche, H. J., Barz, K., Ayon, P., \& Schulz, J. (2014). High resolution vertical distribution of the copepod Calanus chilensis in relation to the shallow oxygen minimum zone off northern Peru using LOKI, a new plankton imaging system. Deep Sea Res. Part I Oceanogr. Res. Pap., 88, 63-73.

Hofmann, A. F., Peltzer, E. T., Walz, P. M., \& Brewer, P. G. (2011). Hypoxia by degrees: Establishing definitions for a changing ocean. Deep. Res. Part I Oceanogr. Res. Pap., 58, 1212-1226. https://doi.org/10.1016/j.dsr.2011.09.004

IOC, SCOR, IAPSO (2010). The international thermodynamic equation of seawater-2010: Calculation and use of thermodynamic properties. Intergovernmental Oceanographic Commission, Manuals and Guides No. 56, UNESCO (English), 196 pp.

Kara, A. B., Rochford, P. A., \& Hurlburt, H. E. (2000). An optimal definition for ocean mixed layer depth. Journal of Geophysical Research, $105,16,803-816,821$.

Keller, A. A., Ciannelli, L., Wakefield, W. W., Simon, V., Barth, J. A., \& Pierce, S. D. (2015). Occurrence of demersal fishes in relation to near-bottom oxygen levels within the California Current large marine ecosystem. Fisheries Oceanography, 24, 162-176. https://doi.org/ $10.1111 /$ fog. 12100

Koslow, J. A., Goericke, R., Lara-Lopez, A., \& Watson, W. (2011). Impact of declining intermediate-water oxygen on deepwater fishes in the California Current. Marine Ecology Progress Series, 436, 207-218. https://doi.org/10.3354/meps09270

Kramer, D., Kalin, M. J., Stevens, E. G., Thrailkill, J. R., \& Zweifel, J. R. (1972). Collection and processing data on fish eggs and larvae in the California Current region. NOAA Tech. Rep. NMFS, CIRC-370, 1-38.

Kreiner, A., Stenevik, E. K., \& Ekau, W. (2009). Sardine Sardinops sagax and anchovy Engraulis encrasicolus larvae avoid regions with low dissolved oxygen concentration in the northern Benguela Current system. Journal of Fish Biology, 74(1), 270-277. https://doi.org/ 10.1111/j.1095-8649.2008.02124.x

Kurczyn, J. A., Beier, E., Lavín, M. F., \& Chaigneau, A. (2012). Mesoscale eddies in the northeastern Pacific tropical-subtropical transition zone: Statistical characterization from satellite altimetry. Journal of Geophysical Research, 117. C10021. https://doi.org/10.1029/ 2012JC007970

Lavaniegos, B. E., Gómez-Gutiérrez, J., Lara-Lara, J. R., \& Hernández-Vázquez, S. (1998). Long-term changes in zooplankton volumes in the California Current System-the Baja California region. Marine Ecology Progress Series, 169, 55-64. 
Lavín, M. F., Beier, E., Gómez-Valdés, J., Godínez, V. M., \& García-Córdova, J. (2006). On the summer poleward coastal current off SW México. Geophysical Research Letters, 33, L02601. https://doi.org/10.1029/2005GL024686

Legendre, P., \& Legendre, L. (1998). Numerical ecology, 2da, (Edici. ed.). Amsterdam, The Netherlands: Elsevier Science B.V.

Longhurst, A. R. (1967). Vertical distribution of zooplankton in relation to the eastern Pacific oxygen minimum. Deep Sea Research and Oceanographic Abstracts, 14, 51-63. https://doi.org/https://doi.org/10.1016/0011-7471(67)90028-9

Madhu, N. V., Jyothibabu, R., Ramu, K., Sunil, V., Gopalakrishnan, T. C., \& Nair, K. K. C. (2003). Vertical distribution of mesozooplankton biomass in relation to oxygen minimum layer in the Andaman Sea during February 1999. Oceanogr: Natl. Inst.

Márquez-Artavia, A., Sáchez-Velasco, L., Barton, E. D., Paulmier, A., Santamaría-del-Ángel, E., \& Beier, E. (2019). A suboxic chlorophyll-a maximum persist within the Pacific oxygen minimum zone off Mexico. Deep Sea Research Part II: Topical Studies in Oceanography. https://doi.org/10.1016/j.dsr2.2019.104686

Mcclatchie, S., Thompson, A. R., Alin, S. R., Siedlecki, S., Watson, W., \& Bograd, S. J. (2016). The influence of Pacific Equatorial Water on fish diversity in the southern California Current System. Journal of Geophysical Research: Oceans, 121, 1-16. https://doi.org/10.1002/ 2016JC011672

Meier, H. E. M., Meier, M., \& Al, E. T. (2018). Recently accelerated oxygen consumption rates amplify deoxygenation in the Baltic Sea Journal of Geophysical Research: Oceans, 123, 3227-3240. https://doi.org/10.1029/2017JC013686

Moser, H. G. (1996). (ed.). The early stages of fishes in the California Current Region. Calif. Coop. Fish. Invest. Rep Atlas No. 33. Allen Press, Inc. Luwerence Kansas 1505 pp.

Moser, H. G., \& Smith, P. E. (1993). Larval fish assemblages of the California Current region and their horizontal and vertical distributions across a front. Bulletin of Marine Science, 53, 645-691.

Pawlowicz, R., Wright, D. G., \& Millero, F. J. (2010). The effects of biogeochemical processes on oceanic conductivity/salinity/density relationships and the characterization of real seawater. Ocean Science Discussions, 7, 773-836.

Portela, E., Beier, E., Barton, E. D., Castro, R., Godínez, V. M., Palacios-Hernández, E., et al. (2016). Water masses and circulation in the tropical Pacific off central Mexico and surrounding areas. Journal of Physical Oceanography, 46, 3069-3081. https://doi.org/10.1175/ JPO-D-16-0068.1

Portela, E., Beier, E., Barton, E. D., \& Sánchez-Velasco, L. (2018). Surface salinity balance in the tropical Pacific off Mexico. Journal of Geophysical Research: Oceans, 123(8), 5763-5776. https://doi.org/10.1029/2018JC014265

Prince, E. D., \& Goodyear, C. P. (2006). Hypoxia-based habitat compression of tropical pelagic fishes. Fisheries Oceanography, 15, 451-464. https://doi.org/10.1111/j.1365-2419.2005.00393.x

Ruvalcaba-Aroche, E. D., Sánchez-Velasco, L., Beier, E., Godínez, V. M., Barton, E. D., \& Pacheco, M. R. (2018). Effects of mesoscale structures on the distribution of cephalopod paralarvae in the Gulf of California and adjacent Pacific. Deep Sea Res. Part I Oceanogr. Res. Pap., 131, 62-74. https://doi.org/https://doi.org/10.1016/j.dsr.2017.11.005

Sánchez-Velasco, L., Beier, E., Godínez, V. M., Barton, E. D., Santamaría-del-Angel, E., Jiménez-Rosemberg, S. P. A., \& Marinone, S. G. (2017). Hydrographic and fish larvae distribution during the "Godzilla El Niño 2015-2016" in the northern end of the shallow oxygen minimum zone of the eastern tropical Pacific Ocean. Journal of Geophysical Research: Oceans, 122, 2156-2170. https://doi.org/10.1002/ 2016JC012622

Sánchez-Velasco, L., Ruvalcaba-Aroche, E. D., Beier, E., Godínez, V. M., Barton, E. D., Díaz-Viloria, N., \& Pacheco, M. R. (2016). Paralarvae of the complex Sthenoteuthis oualaniensis-Dosidicus gigas (Cephalopoda: Ommastrephidae) in the northern limit of the shallow oxygen minimum zone of the eastern tropical Pacific Ocean (April 2012). Journal of Geophysical Research: Oceans, 121, 1998-2015. https://doi. org/10.1002/2015JC011534

Sánchez-Velasco, L., Shirasago, B., Cisneros-Mata, M. A., \& Avalos-García, C. (2000). Spatial distribution of small pelagic fish larvae in the Gulf of California and its relation to the El Niño 1997-1998. Journal of Plankton Research, 22, 1611-1618. https://doi.org/10.1093/ plankt/22.8.1611

Santamaría-del-Ángel, E., González-Silvera, A., Millán-Núñez, R., Callejas-Jiménez, M. E., \& Cajal-Medrano, R. (2011). Determining dynamic biogeographic regions using remote sensing data. Handb. Satell. Remote Sens. Image Interpret. Appl. Mar. Living Resour. Conserv. Manag., 273-293.

Schmidtko, S., Stramma, L., \& Visbeck, M. (2017). Decline in global oceanic oxygen content during the past five decades. Nature, 542(7641), 335-339. https://doi.org/10.1038/nature21399

Smith, P. E. (1971). Distributional atlas of zooplankton volume in the California Current region, 1951, trough 1966. Calif. Coop. Fish. Invest. Rep. Atlas No., 13

Smith, P. E., \& Richardson, S. L. (1979). Tecnicas modelo para prospecciones de huevos y larvas de peces pelágicos. FAO Doc. Tec. Pesca, 175.

Stramma, L., Johnson, G. C., Sprintall, J., \& Mohrholz, V. (2008). Expanding oxygen-minimum zones in the tropical oceans. Science (80-.), 320, 655-658.

Stramma, L., Schmidtko, S., Levin, L. A., \& Johnson, G. C. (2010). Ocean oxygen minima expansions and their biological impacts. Deep Sea Res. Part I Oceanogr. Res. Pap., 57, 587-595.

Tett, P., Gowen, R. J., Painting, S. J., Elliott, M., Forster, R., Mills, D. K., et al. (2013). Framework for understanding marine ecosystem health. Marine Ecology Progress Series, 494, 1-27. https://doi.org/10.3354/meps10539

Tichý, L., \& Chytrý, M. (2007). Statistical determination of diagnostic species for site groups of unequal size. Journal of Vegetation Science, 17, 809. https://doi.org/10.1658/1100-9233(2006)17[809:sdodsf]2.0.co;2

Tiedke, J., Thiel, R., \& Burmester, T. (2014). Molecular response of estuarine fish to hypoxia: A comparative study with ruffe and flounder from field and laboratory. PLOS ONE, 9, e90778.

Tremblay, N., Gómez-Gutiérrez, J., Zenteno-Savín, T., Robinson, C. J., \& Sánchez-Velasco, L. (2010). Role of oxidative stress in seasonal and daily vertical migration of three krill species in the Gulf of California. Limnology and Oceanography, 55, 2570-2584. https://doi.org/ 10.4319/lo.2010.55.6.2570

Vaquer-Sunyer, R., \& Duarte, C. M. (2008). Thresholds of hypoxia for marine biodiversity. Proceedings of the National Academy of Sciences. https://doi.org/10.1073/pnas.0803833105

Wishner, K. F., Seibel, B. A., Roman, C., Deutsch, C., Outram, D., Shaw, C. T., et al. (2018). Ocean deoxygenation and zooplankton: Very small oxygen differences matter. Science Advances, 4, 1-8.

Zeidberg, L. D., \& Robison, B. H. (2007). Invasive range expansion by the Humboldt squid, Dosidicus gigas, in the eastern North Pacific. Proceedings of the National Academy of Sciences, 104, 12,948-12,950. 